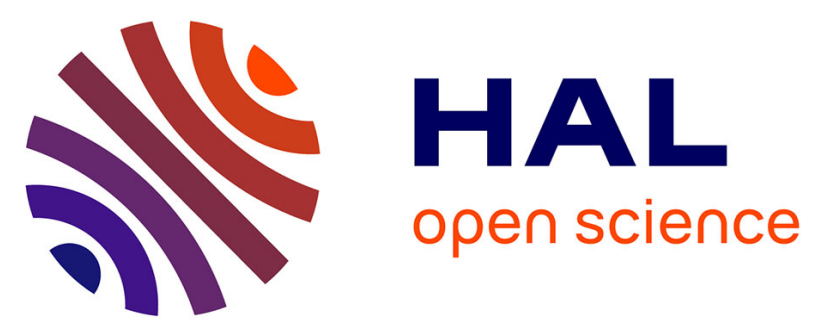

\title{
Physiological Alteration of the Marine Bacterium Vibrio angustum S14 Exposed to Simulated Sunlight During Growth
}

\author{
Maher Abboudi, Sabine Matallana Surget, Jean-Francois Rontani, Richard \\ Sempere, Fabien Joux
}

\section{To cite this version:}

Maher Abboudi, Sabine Matallana Surget, Jean-Francois Rontani, Richard Sempere, Fabien Joux. Physiological Alteration of the Marine Bacterium Vibrio angustum S14 Exposed to Simulated Sunlight During Growth. Current Microbiology, 2008, 57 (5), pp.412-417. 10.1007/s00284-008-9214-9 . hal02058368

\section{HAL Id: hal-02058368 \\ https://hal-amu.archives-ouvertes.fr/hal-02058368}

Submitted on 5 Mar 2019

HAL is a multi-disciplinary open access archive for the deposit and dissemination of scientific research documents, whether they are published or not. The documents may come from teaching and research institutions in France or abroad, or from public or private research centers.
L'archive ouverte pluridisciplinaire HAL, est destinée au dépôt et à la diffusion de documents scientifiques de niveau recherche, publiés ou non, émanant des établissements d'enseignement et de recherche français ou étrangers, des laboratoires publics ou privés.

\section{(c)(1)}

Distributed under a Creative Commons Attribution| 4.0 International License 


\title{
Physiological Alteration of the Marine Bacterium Vibrio angustum S14 Exposed to Simulated Sunlight During Growth
}

\author{
Maher Abboudi · Sabine Matallana Surget • \\ Jean-François Rontani · Richard Sempéré • \\ Fabien Joux
}

Received: 17 April 2008/Accepted: 4 June 2008/Published online: 4 September 2008

\begin{abstract}
Growth experiments on the marine bacterium Vibrio angustum S14 were conducted under four light conditions using a solar simulator: visible light (V), $\mathrm{V}+$ ultraviolet A (UV-A), V + UV-A + UV-B radiation, and dark. Growth was inhibited mainly by UV-B and slightly by UV-A. UV-B radiation induced filaments containing multiple genome copies with low cyclobutane pyrimidine dimers. These cells did not show modifications in cellular fatty acid composition in comparison with dark control cultures and decreased in size by division after subsequent incubation in the dark. A large portion of the bacterial population grown under visible light showed an alteration in cellular DNA fluorescence as measured by flow cytometry after SYBRGreen I staining. This alteration was not aggravated by UVA and was certainly due to a change in DNA topology rather than DNA deterioration because all the cells remained viable and their growth was not impaired. Ecological consequences of these observations are discussed.
\end{abstract}

\section{Introduction}

Marine bacteria are the main contributors in the transfer of carbon from the dissolved phase into the particulate phase

\footnotetext{
M. Abboudi · J.-F. Rontani · R. Sempéré

Laboratoire de Microbiologie Géochimie et Ecologie Marines, CNRS/INSU, UMR 6117, Centre d'Océanologie de Marseille, Université de la Méditerranée, Campus de Luminy, Case 901, F-13288 Marseille Cedex 9, France

S. M. Surget · F. Joux $(\bowtie)$

UPMC Univ Paris 06, CNRS, UMR 7621, Laboratoire

d'Océanographie Biologique de Banyuls, Observatoire

Océanologique, F-66651 Banyuls/mer, France

e-mail: fabien.joux@obs-banyuls.fr
}

(bacterial biomass production) and in the biogenic production of $\mathrm{CO}_{2}$ (bacterial respiration) [2]. In surface waters, solar radiation may have detrimental effects on bacteria by reducing DNA and protein synthesis, exoenzymatic activity and respiration (for a review see Ref. [15]). Solar ultraviolet radiation (UV-R) reaching the Earth's surface constitutes the most damaging part of solar incident radiation for organisms. UV-B (280-320 nm) and UV-A (320-400 nm) cause distinct but overlapping damages. Exposure to UV-B mainly has a direct effect on DNA by inducing dimerization of DNA bases and blocking DNA transcription and replication. The effects of exposure to UV-A, and to a lesser visible light (400-700 nm), are mainly indirect, by generation of reactive oxygen species (ROS) which interact with DNA, proteins, and lipids to induce damages that may be lethal or mutagenic [9]. However, bacteria can efficiently repair UV-induced DNA damage by (i) photoreactivation after activation of the photolyase enzyme by light in the range of 380-430 $\mathrm{nm}$ and (ii) "dark" DNA repair mechanisms including nucleotideexcision repair, SOS-error-prone repair, and postreplication recombinational repair.

Adaptative responses of bacteria to grow under solar radiation are of great interest to understand how bacteria can face the challenge of synthesizing DNA under damaging photons. Although extensive research has been carried out on the effect of solar radiation on bacteria, most of it has been conducted to measure the resistance of cells exposed in a nongrowing state (e.g., Ref. [16]). The capacity of heterotrophic bacteria to grow under light stress has been much less studied [3] and, to our knowledge, never for marine bacteria. The objective of this study was to determine how different parts of solar radiation might affect the growth, viability, cell size, DNA content, DNA damage, and fatty acid (FA) contents of the marine bacterium Vibrio angustum S14 [18]. 


\section{Materials and Methods}

Bacterial Strain and Growth Experiments Under Simulated Solar Exposure V. angustum S14 (UNSW, Sydney, Australia) was grown in an artificial seawater medium supplemented with $3 \mathrm{mM}$ D-glucose (ASW-G) [8] at $30^{\circ} \mathrm{C}$ with orbital shaking at $130 \mathrm{rpm}$. Cylindrical quartz flasks with a flat top containing $200 \mathrm{ml}$ of ASW-G and a magnetic stirrer were inoculated with $2 \mathrm{ml}$ of an overnight preculture. Culture flasks were then exposed to simulated sunlight produced by a solar-filtered (1.0 air mass) 1000-W xenon arc lamp (Oriel Corp., Stratford, CT, USA) giving an optical output irradiance of $250 \mathrm{~W} \mathrm{~m}^{-2}$ PAR, $19.3 \mathrm{~W} \mathrm{~m}^{-2} \mathrm{UV}-\mathrm{A}$, and $0.85 \mathrm{~W} \mathrm{~m}^{-2} \mathrm{UV}-\mathrm{B}$ as measured with a UV/visible RAMSES spectroradiometer (TriOS, Germany). Four light treatments were studied simultaneously: (i) full radiation (visible+UV-A+UV-B; culture flask covered with acetate cellulose [50\% transmission at $280 \mathrm{~nm}$ ] to remove residual UV-C), (ii) visible light and UV-A (culture flask covered with Mylar film [50\% transmission at $320 \mathrm{~nm}]$ ), (iii) visible light (culture flask covered with OP3 [50\% transmission at $400 \mathrm{~nm}$ ]), and (iv) dark (culture flask covered with black tape). The four culture flasks were maintained at $30^{\circ} \mathrm{C}$ by partial submersion in a water bath connected to a cryothermostat with continuous magnetic stirring $(\sim 100 \mathrm{rpm})$. Culture flasks were irradiated during $12 \mathrm{~h}$ under the solar simulator (i.e., until the stationary phase) and then maintained in the dark for $12 \mathrm{~h}$. Growth was monitored by optical density (OD) measurements at $433 \mathrm{~nm}$. Colony-forming units (CFU) were determined at $\mathrm{T}_{0}, \mathrm{~T}_{12 \mathrm{~h}}$, and $\mathrm{T}_{24 \mathrm{~h}}$ by plating appropriate dilutions in triplicate on VNSS media [8]. CFU were counted after incubation at $30^{\circ} \mathrm{C}$ during $24 \mathrm{~h}$.

Flow Cytometry and Epifluorescence Analysis Samples fixed with formaldehyde (2\% final concentration) were analyzed at $\mathrm{T}_{0}, \mathrm{~T}_{6 \mathrm{~h}}, \mathrm{~T}_{12 \mathrm{~h}}$, and $\mathrm{T}_{24 \mathrm{~h}}$ on a flow cytometer (FACSCalibur; Becton Dickinson, San Jose, CA, USA) after staining with the nucleic acid dye SYBR Green I (Molecular Probes Inc., Eugene, OR, USA) [1]. Bacteria were detected on a plot of green fluorescence (515$545 \mathrm{~nm}$ ) versus right-angle light scatter (SSC), using the green fluorescence as the threshold parameter. Fluorescence beads $(1.0 \mu \mathrm{m}$; Polysciences Inc., Warrington, PA, USA) were added to each sample analyzed to normalize SSC and green fluorescence. Cells were also observed with an epifluorescence microscope (AX70; Olympus Provis) after staining with 4',6-diamidino-2-phenylindole (DAPI; $2.5 \mu \mathrm{g} \mathrm{ml}^{-1}$; Sigma).

Cyclobutane Pyrimidine Dimers Analysis CPDs were quantified at $\mathrm{T}_{0}, \mathrm{~T}_{12 \mathrm{~h}}$, and $\mathrm{T}_{24 \mathrm{~h}}$ by an enzyme-linked immunosorbent assay (ELISA). DNA was isolated from $20 \mathrm{ml}$ of culture using the Wizard genomic DNA purification kit (Promega) and quantified using the QuantiT PicoGreen dsDNA assay kit (Molecular Probes, Invitrogen). One hundred nanograms of each DNA sample was added to $1 \%$ protamine sulfate-treated wells in 96-well ELISA plates. The primary antibody against CPD (MC062; Kamiya Biomedical Company) and the secondary antibody, a horseradish peroxidase conjugate (HRP rabbit anti-mouse IgG; Invitrogen Molecular Probes), was diluted $1: 1000$ and $1: 2000$, respectively, in $0.05 \%$ Tween-20/ $0.25 \%$ bovine serum albumin (BSA) $/ 1 \times$ phosphate-buffered saline blocking solution. Photoproducts were quantified at $\mathrm{OD}_{492 \mathrm{~nm}} 30 \mathrm{~min}$ after enzyme reaction with $O$-phenylenediamine dihydrochloride (Sigma) after stopping the reaction with $\mathrm{H}_{2} \mathrm{SO}_{4}(2 \mathrm{M})$. OD was calibrated using standards (0-1000 CPD/Mb DNA) of UV-B-irradiated calf thymus DNA (Sigma) for which CPDs were quantified by high-performance liquid chromatographytandem mass spectrometry [7].

Fatty Acid Analysis Bacteria sampled at $\mathrm{T}_{12} \mathrm{~h}$ under dark and V+UV-A+UV-B conditions were saponified [23] and total FA fractions were then silylated and analyzed by gas chromatography-mass spectrometry (GC-MS). GC-MS analyses under electron ionization (GC-EIMS) were carried out with an HP 6890 gas chromatograph connected to an HP 5973 mass spectrometer. Structural assignments were based on interpretation of mass spectrometric fragmentations and confirmed by comparison of retention times and mass spectra with those of authentic compounds, when these were available.

\section{Results and Discussion}

Effect of UV-B, UV-A, and Visible Light on Bacterial Growth According to the OD, the maximum growth rate of $V$. angustum in darkness was $\sim 1 \mathrm{~h}^{-1}$ (Fig. 1). The bacterial cultures reached the stationary phase after $12 \mathrm{~h}$ for all light conditions. During the midlog phase $\left(\mathrm{T}_{6} \mathrm{~h}\right)$ there were significant differences in OD measured under the different light conditions (dark $>$ visible $>\mathrm{V}+\mathrm{UV}-\mathrm{A}>\mathrm{V}+\mathrm{UV}-\mathrm{A}+\mathrm{UV}-\mathrm{B}$ ) (Mann Whitney $U$-test, $p<0.05$ ), suggesting gradual inhibition of growth due to the different band parts of sunlight. However, in the stationary phase $\left(\mathrm{T}_{12} \mathrm{~h}\right)$, the cell yield was significantly lower only for the $\mathrm{V}+\mathrm{UV}-\mathrm{A}+\mathrm{UV}-\mathrm{B}$ condition $(-18 \%)$ compared to the other conditions $(p<0.05)$. During the dark period, the OD declined slightly for all conditions except for $\mathrm{V}+\mathrm{UV}-\mathrm{A}+\mathrm{UV}-\mathrm{B}$, for which OD was stable. Cell enumerations measured by flow cytometry showed patterns different from those of the OD. First, an inhibition at midlog phase was observed only for the $\mathrm{V}+\mathrm{UV}-\mathrm{A}$ and $\mathrm{V}+\mathrm{UV}-$ A+UV-B conditions $(-65 \%$ and $-89 \%$ compared to the dark condition, respectively; $p<0.05)$. Second, the cell 
Fig. 1 Growth curves of $V$. angustum S14 in ASW-G at $30^{\circ} \mathrm{C}$ under different light treatments. Cell growth was measured as optical density at $433 \mathrm{~nm}\left(\mathrm{OD}_{433 \mathrm{~nm}}\right)$ (a) and cell number measured by flow cytometry (b). The open bar represents the period of simulated sunlight exposure and the black bar represents the period of darkness. Points are represented as the average of at least three independent experimental values; error bars are $1 \mathrm{SD}$

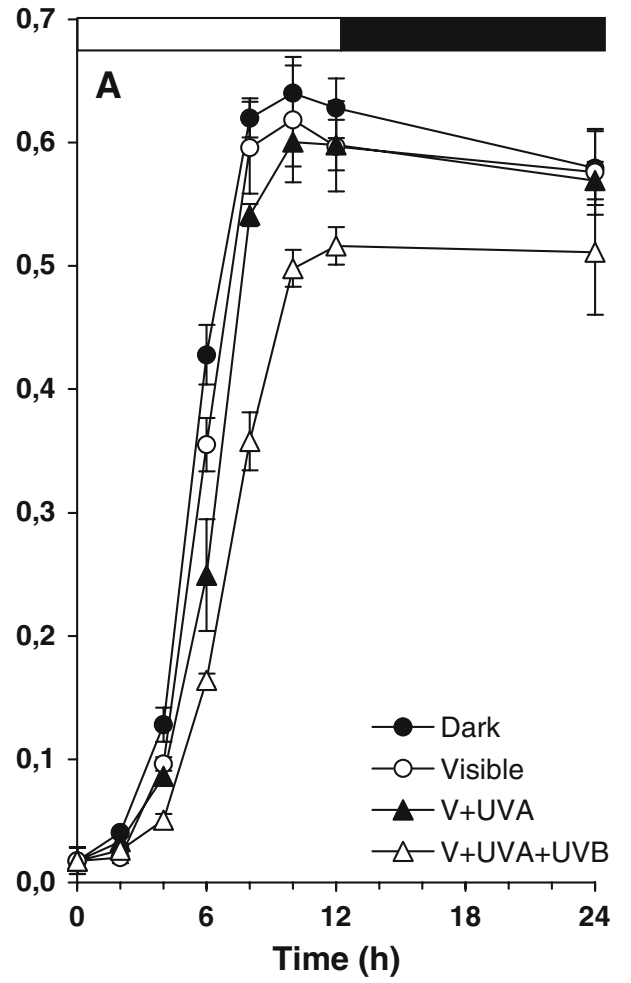

number continued to increase during the dark period (between $\mathrm{T}_{12 \mathrm{~h}}$ and $\mathrm{T}_{24 \mathrm{~h}}$ ) for all conditions. This increase was more pronounced in $\mathrm{V}+\mathrm{UV}-\mathrm{A}+\mathrm{UV}-\mathrm{B}$ cultures $(+190 \%)$ compared to the others $(+63 \%$ to $86 \% ; p<0.05)$. The measurement of OD may differ from that of flow cytometry because it combines both cell number and cell size (e.g., the same OD can be obtained with more cells but with a smaller size; see below).

Viability remained high in all cultures and not significantly different from $100 \%$ at $\mathrm{T}_{12 \mathrm{~h}}$ (Table 1). During the prolongation of the stationary phase in the dark, a slight decrease in the percentages of viable cells was detected in visible and $\mathrm{V}+\mathrm{UV}-\mathrm{A}$ cultures, however, these variations must be interpreted with caution because of the imprecision in the methods used to enumerate CFU and total cells. Low quantities of CPDs (close to the detection limit of the method) were detectable in bacteria exposed to $\mathrm{V}+\mathrm{UV}$ $\mathrm{A}+\mathrm{UV}-\mathrm{B}$ at $\mathrm{T}_{12 \mathrm{~h}}$ and $\mathrm{T}_{24 \mathrm{~h}}$, but not for the other conditions, highlighting the importance of UV-B in the induction of this DNA damage (Table 1).

The sunlight intensity used in this study corresponds to $\sim 60 \%$ of the maximal solar intensity that we can measure in summer in the Mediterranean region, however, the cumulative dose over the $12 \mathrm{~h}$ of irradiation was similar to that measured daily in the same region [1]. The faculty of $V$. angustum S14 to grow under the irradiance used in this study emphasizes the high resistance of this strain to light stress, and the low level of CPDs accumulated during its growth under full sunlight suggests active DNA repair activity in this bacterium. The quantity of CPDs measured in these cells corresponds to the levels of residual damage in marine bacteria present at the surface before sunrise [4]. Photoreactivation may be particularly important in $V$. angustum S14 to repair DNA damage as already reported for other vibrio species [16, 20].

Changes in Cellular DNA Fluorescence According to the DNA fluorescence analyzed by flow cytometry, bacteria in the inocula were equally composed of cells containing one and two fully replicated genomes (Fig. 2a). After $12 \mathrm{~h}$ of culture in darkness (stationary phase), the bacterial population was composed of cells containing two and four genomes (Fig. 2b). During the subsequent $12 \mathrm{~h}$ of culture, multigenomic cells divided by decreasing in size (from 1.7 to $1.4 \mu \mathrm{m}$ in length) to give bacteria with a DNA content similar to that of cells observed in the inocula (data not shown). This process, called reductive division, results from the fact that initiated rounds of DNA replication and cell division are completed in the absence of further growth upon entry of cells into the stationary phase [22] and has been reported for other marine Vibrio [25].

For cultures under visible light we observed a profound alteration in DNA fluorescence at $\mathrm{T}_{12} \mathrm{~h}$ (Fig. 2c). A similar alteration was observed in V+UV-A culture (Fig. 2d), suggesting the predominant role of visible light in this alteration. According to the fluorescence of cells containing a single genome observed in the inocula and in the cultures at $\mathrm{T}_{24 \mathrm{~h}}$ in darkness, we defined a threshold below which cells 
Table 1 Changes in length, width, percentage colony forming units (CFU), and cyclobutane pyridine dimers (CPDs) during growth in different light treatments: data are the average (standard deviation) of at least two independent experiments

a Expressed as a percentage of
total counts

\begin{tabular}{|c|c|c|c|c|c|}
\hline $\begin{array}{l}\text { Light } \\
\text { treatment }\end{array}$ & $\begin{array}{l}\text { Incubation } \\
\text { time (h) }\end{array}$ & $\begin{array}{l}\text { Length } \\
(\mu \mathrm{m})\end{array}$ & $\begin{array}{l}\text { Width } \\
(\mu \mathrm{m})\end{array}$ & $\% \mathrm{CFU}^{\mathrm{a}}$ & $\begin{array}{l}\text { CPDs } \\
\text { (/Mb DNA) }\end{array}$ \\
\hline All & 0 & $1.9(0.4)$ & $1.2(0.2)$ & $104(46)$ & 0 \\
\hline \multirow[t]{2}{*}{ Dark } & 12 & $1.7(0.4)$ & $1.0(0.2)$ & $91(12)$ & 0 \\
\hline & 24 & $1.4(0.3)$ & $1.1(0.2)$ & $68(3)$ & 0 \\
\hline \multirow[t]{2}{*}{ Visible } & 12 & $1.7(0.5)$ & $1.0(0.2)$ & $102(2)$ & 0 \\
\hline & 24 & $1.5(0.4)$ & $1.0(0.2)$ & $94(15)$ & 0 \\
\hline \multirow[t]{2}{*}{$\mathrm{V}+\mathrm{UV}-\mathrm{A}$} & 12 & $1.7(0.6)$ & $0.9(0.2)$ & 107 (2) & 0 \\
\hline & 24 & $1.5(0.5)$ & $1.0(0.2)$ & $73(3)$ & 0 \\
\hline \multirow{2}{*}{$\begin{array}{l}\mathrm{V}+\mathrm{UV}-\mathrm{A}+\mathrm{UV}- \\
\mathrm{B}\end{array}$} & 12 & $42(36.6)$ & $1.2(0.2)$ & 77 (11) & 24.3 (11.4) \\
\hline & 24 & $4.8(9.2)$ & $1.1(0.3)$ & $74(22)$ & 8.7 (12.4) \\
\hline
\end{tabular}

were called DNA-. The proportion of DNA- increased continuously in cultures under the visible condition, to reach $45 \%$ at $\mathrm{T}_{24 \mathrm{~h}}$ (Fig. 3c). The $\mathrm{V}+\mathrm{UV}-\mathrm{A}$ condition showed a similar pattern, whereas $\mathrm{V}+\mathrm{UV}-\mathrm{A}+\mathrm{UV}-\mathrm{B}$ presented fewer DNA- cells at $\mathrm{T}_{12 \mathrm{~h}}(10 \%)$ and $\mathrm{T}_{24 \mathrm{~h}}(25 \%)$ (Fig. 3c). The lower staining observed in cells grown under visible and $\mathrm{V}+\mathrm{UV}-\mathrm{A}$ conditions cannot be due to a modification of the membrane permeability for the fluorescent dye, because cells were fixed with formaldehyde, or to a degradation of DNA, because all the cells were viable. We hypothesize that growth under high irradiance (mainly due to visible light) could induce a change in DNA topology that could have an impact on fluorochrome fixation on DNA. In bacteria, supercoiling of the circular chromosome is under the control of several topoisomerases that maintain the optimum conformation of the DNA for processes like transcription and DNA replication [21]. The decrease in DNA negative supercoiling has been observed in Escherichia coli after visible light irradiation and treatment with hydrogen peroxide [13, 27]. Yet there is no evidence that relaxation of DNA is sufficient to induce a change in in vivo SYBR fluorescence, and further studies are required to test this hypothesis. These studies may help clarify the role of light and oxidative stress in the heterogeneity of DNA fluorescence revealed by flow cytometry in bacterial communities of aquatic ecosystems after fluorescent nucleic acid staining [5].

Cell Filamentation Cells grown under visible or V+UVA light or in the dark showed similar sizes when examined by epifluorescence microcospy (Table 1) and similar SSC measured by flow cytometry (Fig. 3a) at $\mathrm{T}_{12 \mathrm{~h}}$ and $\mathrm{T}_{24 \mathrm{~h}}$. In contrast, we observed filamentous bacteria with variable lengths for the $\mathrm{V}+\mathrm{UV}-\mathrm{A}+\mathrm{UV}-\mathrm{B}$ condition after $12 \mathrm{~h}$ of growth (Table 1). These cells showed a mean SSC and a mean DNA fluorescence 2 and 1.5 times higher, respectively, than those of bacteria cultivated in darkness (Fig. 3a, b). According to the fluorescence of cells with one genome, filaments contained a mean of eight genomes
Fig. 2 SYBR-Green I fluorescence versus side scatter cytograms of $V$. angustum S14 in the inocula (a) and after $12 \mathrm{~h}$ of growth in darkness (b), visible light (c), visible+UV-A light (d), and visible $+\mathrm{UV}$ A+UV-B light (e). DNA- area circumscribes the cells with an apparent DNA content less than one genome
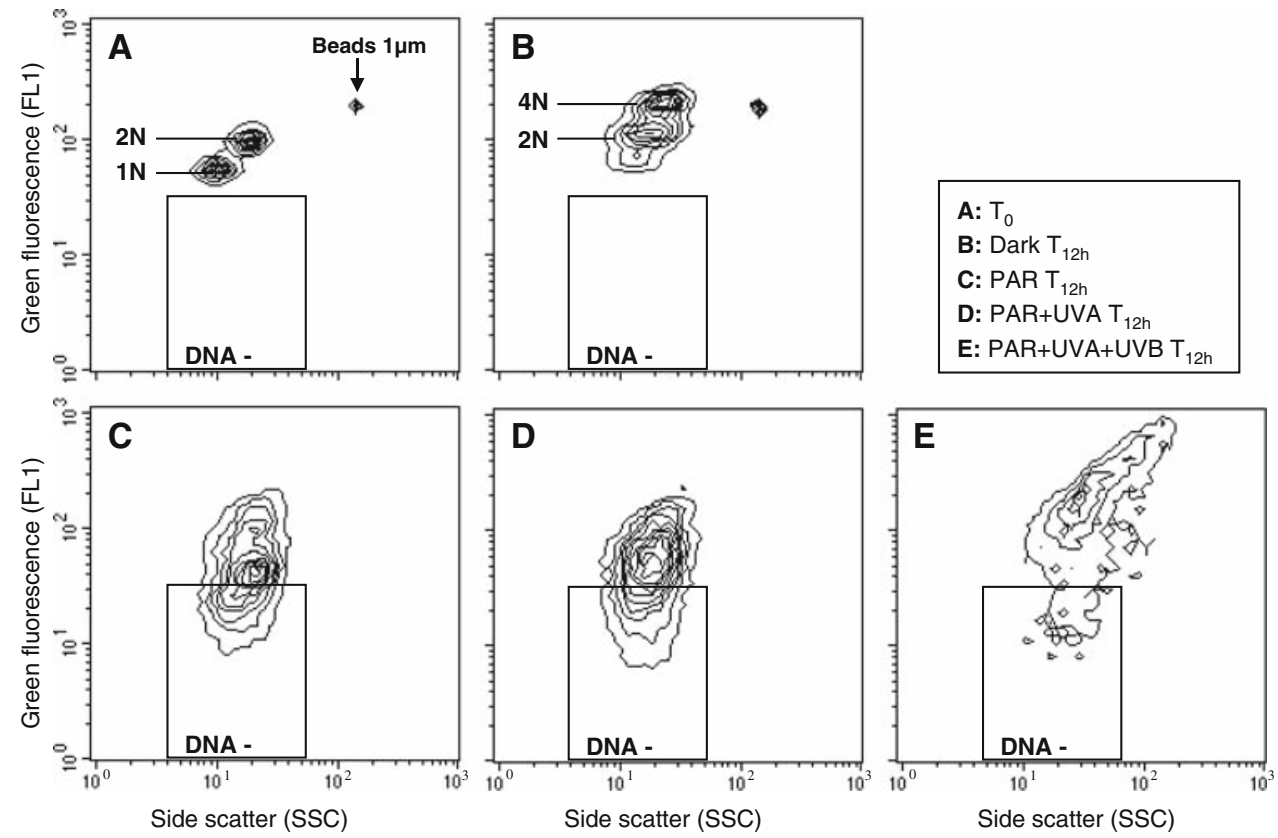
Fig. 3 Change in relative side scatter (a), DNA green fluorescence (b), and percentages of DNA- cells (c) during the growth of $V$. angustum S14 under the different light treatments. The open bar represents the period of simulated sunlight exposure and the dark bar represents the period of darkness. Points represented are the average of at least two independent experimental values; error bars are $1 \mathrm{SD}$

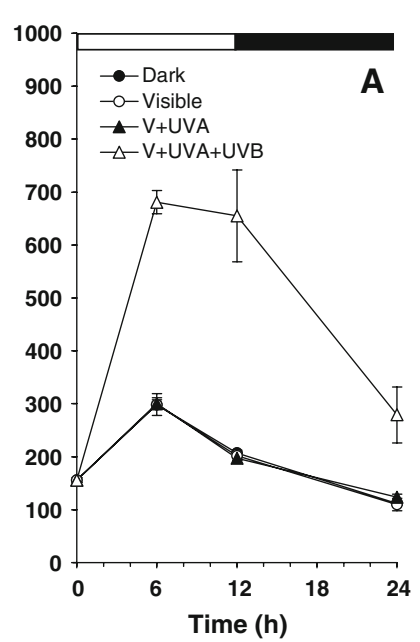

Time (h) copies. After the dark period, these filamentous cells decreased in size (Table 1) and in cellular DNA fluorescence (Fig. 3b). Cell filamentation is a well-known process induced by the SOS response after different physical or chemical treatments that damage DNA (e.g., UV-R) or inhibit DNA replication (e.g., nalidixic acid, thymine starvation) [14]. The SOS response is a strategy employed by bacterial cells to inhibit cell division while damaged DNA is repaired, thereby preventing the transmission of deleterious mutations to daughter cells. Here we observed that filamentation was induced by UV-B but not by UV-A or visible light. Induction of filamentous bacteria in aquatic ecosystems has already been reported for some bacterial species as a mechanism for grazing resistance [17] but never, to our knowledge, as a response to UV-R. The degree of filamentation certainly depends on the available substrates and the growth rate of bacteria. Because the growth rate of bacteria in aquatic systems is well below that of $V$. angustum in this study, we can expect that filamentation induced by UV-R is also certainly less important. If this process occurs, but insufficiently to form long filamentation, these bigger bacteria may be more prone to grazing than smaller cells.

Fatty Acid Composition The FA composition was analyzed in cells after $12 \mathrm{~h}$ of growth under V+UV-A+UV-B (filamentous cells) and dark conditions (Table 2). Both cells presented very similar FA profiles, dominated by palmitoleic acid. Saturated (SFA) and monoinsatured (MUFA) FA represented $\sim 55 \%$ and $\sim 35 \%$ of the total FA, respectively. The remaining fraction corresponded to unknown compounds and hydroxyacid. Polyunsaturated fatty acids (PUFA) were absent. The FA composition measured in $V$. angustum is congruent with those measured in other Vibrio species [26]. The few published papers dealing with the effects of UV-R on the FA composition of marine organisms concern microalgae and they reported
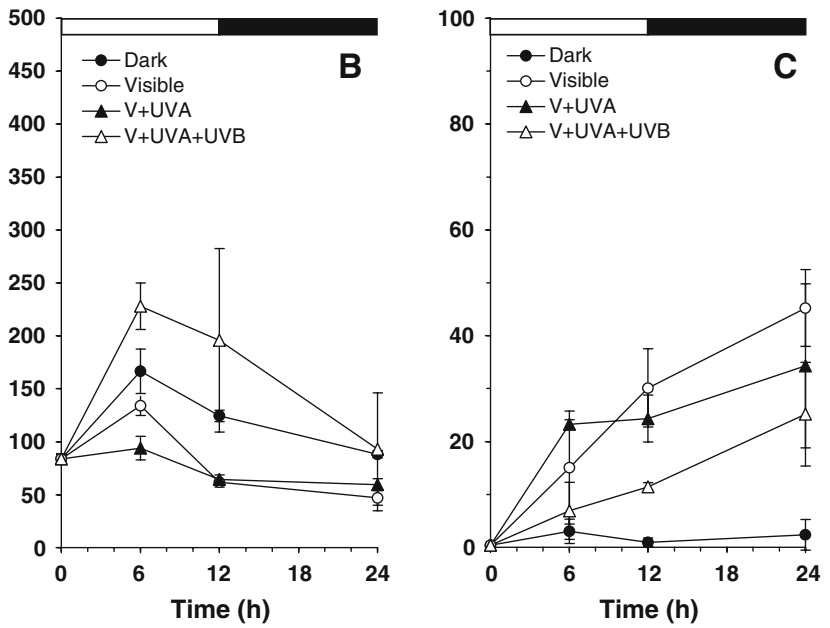

Table 2 Fatty acid (FA) composition of $V$. angustum S14 after $12 \mathrm{~h}$ of growth in the dark or under visible+UV-A+UV-B light: results expressed as the percentage of total FA (range) from two independent experiments

\begin{tabular}{lcc}
\hline Main FA & \multicolumn{2}{l}{ Light treatment } \\
\cline { 2 - 3 } & Dark & $\mathrm{V}+\mathrm{UV}-\mathrm{A}+\mathrm{UV}-\mathrm{B}$ \\
\hline Palmitoleic acid $\left(\mathrm{C}_{16: 1}\right)$ & $50.6(49.3-51.9)$ & $50.1(47.5-52.7)$ \\
Palmitic acid $\left(\mathrm{C}_{16: 0}\right)$ & $26.1(20.4-31.8)$ & $30.3(27.0-33.7)$ \\
3-OH-C $12: 0$ & $9.4(5.9-12.8)$ & $7.9(4.5-11.4)$ \\
Vaccenic acid $\left(\mathrm{C}_{18: 1}\right)$ & $4.7(3.5-5.8)$ & $3.6(3.0-4.2)$ \\
Myristic acid $\left(\mathrm{C}_{14: 0}\right)$ & $4.2(4.1-4.3)$ & $3.7(3.1-4.3)$ \\
Lauric acid $\left(\mathrm{C}_{12: 0}\right)$ & $3.4(1.9-4.9)$ & $2.9(1.1-4.7)$ \\
Unknown & $1.7(1.1-2.4)$ & $1.5(0.8-2.2)$ \\
Total saturated FA & $55.3(55.8-57.7)$ & $53.7(50.5-56.9)$ \\
Total monounsaturated FA & $33.7(26.4-41.0)$ & $36.9(31.2-42.7)$ \\
\hline
\end{tabular}

contradictory results. Indeed, as the response to UV-R, the authors observed (i) an increase in the proportion of PUFA $[6,11,19]$, (ii) no significant differences in the FA profiles [24], and (iii) an increase in the proportion of SFA [10, 12]. Alterations of the FA profiles could result from (i) photosensitized degradation processes induced by sensitizer substances present in these organisms or (ii) changes in the biosynthesis of these compounds as a response to light stress. The stability of the FA composition of $V$. angustum S14 observed in the present work shows that UV-R cannot induce FA photodegradation in this bacterium, probably due to the lack of adequate photosensitizers, and that biosynthesis pathways of FA are not modified as a response to light stress. This first study on the effects of UV-R on the FA composition of a heterotrophic bacterium must be completed with other bacterial species knowing that important diversity of FA composition exists for these bacteria. It has been observed that changes in FA composition of phytoplankton induced by UV-R could have 
modified the food quality, leading to a reduction in predator growth [6, 12]. Grazing experiments using bacteria grown under UV-R could also be conducted to determine if changes in food quality, which may concern constituents other than FA, occur due to UV-R.

Acknowledgments We thank T. Douki for determination CPDs by HPLC-MS/MS for standard samples. We are grateful to N. West for improvement of the language. This study was funded by the CNRSINSU through the UVECO and ATIPE projects and by a fellowship from the Syrian Atomic Energy Commission to M.A.

\section{References}

1. Abboudi M, Jeffrey WH, Ghiglione J-F, Pujo-Pay M, Oriol L, Sempéré R, Charrière B, Joux F (2008) Effects of photochemical transformations of dissolved organic matter on bacterial metabolism and diversity in three contrasting coastal sites in the Northwestern Mediterranean Sea during summer. Microb Ecol 55:344-357

2. Azam F, Fenchel T, Field GJ, Gray JS, Meyer-Reil AL, Thingstad F (1983) The ecological role of water-column microbes in the sea. Mar Ecol Prog Ser 10:257-263

3. Berney M, Weilnemann HU, Egli T (2007) Adaptation to UVA radiation of $E$. coli growing in continuous culture. J Photochem Photobiol B Biol 86:149-159

4. Boelen P, Post AF, Veldhuis MJ, Buma A (2002) Diel patterns of UVBR-induced DNA damage in picoplankton size fractions from the Gulf of Aqaba, Red Sea. Microb Ecol 44:164-174

5. Bouvier T, del Giorgio PA, Gasol JM (2007) A comparative study of the cytometric characteristics of High and Low nucleicacid bacterioplankton cells from different aquatic ecosystems. Environ Microbiol 9:2050-2066

6. De Lange HJ, Van Donk E (1997) Effects of UVB-irradiated algae on life history traits of Daphnia pulex. Freshwat Biol 38:711-720

7. Douki T, Cadet J (2001) Individual determination of the yield of the main-UV induced dimeric pyrimidine photoproducts in DNA suggests a high mutagenicity of CC photolesions. Biochemistry 40:2495-2501

8. Eguchi M, Nishikawa T, MacDonald K, Cavicchioli R, Gottschal JC, Kjelleberg S (1996) Responses to stress and nutrient availability by the marine ultramicrobacterium Sphingomonas sp. strain RB2256. Appl Environ Microbiol 62:1287-1294

9. Elasri OM, Miller VR (1999) Study of the response of a biofilm bacterial community to UV radiation. Appl Environ Microbiol 65:2025-203

10. Goes JI, Handa N, Taguchi S, Hama T (1994) Effect of UV-B radiation on the fatty acid composition of the marine phytoplankter Tetraselmis sp.: relationship to cellular pigments. Mar Ecol Prog Ser 114:259-274
11. Gupta R, Bhadauriya P, Chauhan VS, Bisen PS (2008) Impact of UV-B radiation on thylakoid membrane and fatty acid profile of Spirulina platensis. Curr Microbiol 56:156-161

12. Hessen DO, DeLange HJ, Van Donk E (1997) UV-induced changes in phytoplankton cells and its effects on grazers. Freshwat Biol 38:513-524

13. Horiuchi H, Takagi M, Yano K (1984) Relaxation of supercoiled plasmid DNA by oxidative stresses in Escherichia coli. J Bacteriol 160:1017-1021

14. Janion C (2001) Some aspects of the SOS response system-a critical survey. Acta Biochim Pol 48:599-610

15. Jeffrey WH, Kase JP, Wilhelm SW (2000) Ultraviolet radiation effects on bacteria and viruses in marine ecosystems. In: Mora S, Demers S, Vernet M (eds) The effects of UV radiation on marine ecosystems. Cambridge University Press, Cambridge, pp 206236

16. Joux F, Jeffrey WH, Lebaron P, Mitchell DL (1999) Marine bacterial isolates display diverse responses to UV-B radiation. Appl Environ Microbiol 65:3820-3827

17. Jürgens K, Güde H (1994) The potential importance of grazingresistant bacteria in planktonic systems. Mar Ecol Prog Ser 112:169-188

18. Kjelleberg S, Alberston N, Flardh K, Holmquist L, Jouper-Jan A, Marouga R, Ostling J, Svenblad B, Weichart D (1993) How do non-differentiating bacteria adapt to starvation? Antonie Van Leeuwenhoek 63:333-341

19. Liang L, Beardall J, Heraud P (2006) Effects of nitrogen source and UV radiation on the growth, chlorophyll fluorescence and fatty acid composition of Phaeodactylum tricornutum and Chaetoceros muelleri (Bacillariophyceae). J Photochem Photobiol B:Biol 82:161-172

20. Liltved H, Landfald B (1996) Influence of liquid holding recovery and photoreactivation on survival of ultraviolet-irradiated fish pathogenic bacteria. Wat Res 30:1109-1114

21. Luttinger A (1995) The twisted 'life' of DNA in the cell: bacterial topoisomerases. Mol Microbiol 15:601-606

22. Nyström T (2004) Stationary-phase physiology. Annu Rev Microbiol 58:161-181

23. Rontani J-F, Christodoulou S, Koblizek M (2005) GC/MS structural characterization of fatty acids of marine aerobic anoxygenic phototrophic bacteria. Lipids 40:97-108

24. Skerratt JH, Davidson AD, Nichols PD, McMeekin TA (1998) Effect of UV-B radiation on lipid content of three Antarctic marine phytoplankton. Phytochemistry 49:999-1007

25. Smigielski AJ, Wallace B, Marshall KC (1990) Genes responsible for size reduction of marine Vibrios during starvation are located on the chromosome. Appl Environ Microbiol 56:1645-1648

26. Thompson FL, Iida T, Swings J (2004) Biodiversity of vibrios. Microb Mol Biol Rev 68:403-431

27. Weinstein-Fischer D, Elgrably-Weiss M, Altuvia S (2000) Escherichia coli response to hydrogen peroxide: a role for DNA supercoiling, Topoisomerase I and Fis. Mol Microbiol 35:14131420 